\title{
RANCANG BANGUN APLIKASI LAYANAN E-COMMERCE TEMPAT OLEH-OLEH WISATA ANYER
}

\author{
${ }^{1}$ Suherman, ${ }^{2}$ Faturohman Aziz \\ ${ }^{1}$ Program Studi Informatika, ${ }^{1}$ Program Studi Informatika \\ ${ }^{1,2}$ Fakultas Teknologi Informasi Universitas Serang Raya \\ ${ }^{1}$ suherman. unsera@gmail.com
}

\begin{abstract}
E-commerce adalah model operasi bisnis yang sedang berkembang pesat pada era digital ini. Semakin banyak pelaku bisnis dan juga customer yang memanfaatkan e-commerce sebagai sarana bisnis mereka, Sehingga telah mempengaruhi kehidupan sosial dan ekonomi masyarakat pada umumnya. Daerah pariwisata termasuk kawasan wisata pantai anyer juga memiliki potensi produk yang menarik dan belum memiliki akses untuk dikembangkan. Pada saat studi kasus awal ke tempat oleh-oleh wisata Anyer dan melakukan wawancara kepada beberapa pihak wisatawan yang berkunjung, diantaranya memiliki beberapa masalah diantara yaitu belum adanya pemasaran produk secara online, serta pemesanan barang yang harus datang ke toko. Permasalahan yang muncul tersebutlah yang menjadi latar belakang untuk dibangunnya sistem penjualan elektronik (e-commerce) dengan tujuan untuk memudahkan pemasaran produk, mempermudah pengelolaan laporan, serta mempermudah konsumen untuk melakukan pemesanan barang tanpa harus datang ke toko. Adapun model e-commerce yang digunakan adalah mode $C 2 C$ (Consumer to consumer) yaitu aktivitas bisnis (penjualan) yang dilakukan oleh individu (konsumen) kepada individu (konsumen) lainnya dengan tujuan untuk melakukan proses transaksi jual beli. Pada penelitian ini akan dibahas tentang sistem yang digunakan dalam website sebagai sarana jual beli, proses informasi produk, pemesanan produk dan metode pembayaran yang digunakan
\end{abstract}

Kata Kunci : Website, E-commerce, C2C (Consumer to consumer).

\section{PENDAHULUAN}

Daerah pariwisata pantai seperti Anyer tentunya mempunyai banyak potensi yang ditawarkan dan tentunya bisa dijual kepada konsumen, salah satunya yaitu buah tangan khas daerah, tak terkecuali daerah pesisir pantai Anyer yang memiliki banyak keunikan seperti makanan khas , aksesoris, souvenir dan lain sebagainya. Dengan adanya layanan E-commerce, diharapkan memudahkan

para penjual untuk memperoleh keuntungan dan juga memudahkan para konsumen untuk medapatkan barang yang diinginkan dengan mudah.
Salah satu kendala yang sangat Menurut Onno W. Purbo dan Aang Arif Wahyudi dalam David Baum (2001:2) memberikan pengertian " $E$ commerce sebagai satu set dinamis teknologi, aplikasi, dan proses bisnis yang menghubungkan perusahaan, konsumen, dan komunitas tertentu melalui transaksi elektronik dan perdagangan barang, pelayanan, dan informasi yang dilakukan secara elektronik". Dapat disimpulkan bahwa Ecommerce yaitu berarti membeli atau menjual secara elektronik yang dilakukan pada jaringan internet. $E$ commerce terlihat lebih nyata, dengan adanya kebutuhan penjual dan pembeli untuk melakukan transaksi. 
Berdasarkan hasil data seratus responden dari kuisioner yang disebarkan kepada wisatawan pantai Anyer yang telah peneliti lakukan, ditemukan berbagai macam permasalahan yang dihadapi oleh wisatawan yang ingin membeli oleh-oleh khas Anyer, seperti belum tersedianya sarana penjualan secara online yang bisa

mempermudah konsumen untuk mendapatkan barang yang mereka inginkan tanpa harus datang ke toko. Konsumen harus datang sendiri ke lokasi untuk mendapatkan barang yang mereka inginkan, tentunya hal ini menghabiskan waktu dan tenaga sehingga konsumen menginginkan adanya kemudahan layanan yang membuat pelanggan tidak perlu datang ke toko. Di era yang serba canggih saat ini, smartphone bisa melakukan banyak hal dan juga bisa menjalankan berbagai macam aplikasi sebagai sarana hiburan, jejaring sosial media hingga proses jual-beli sebagai media transaksi..

Dalam penelitian ini, alat ukur jarak Berdasarkan hal-hal yang berkaitan diatas maka maka peneliti mencoba membangun sebuah aplikasi toko oleh-oleh wisata Anyer Berbasis Web untuk mempermudah dalam pencapaian tujuan yang diharapkan.

\section{METODE PENELITIAN}

$$
\text { Metode yang dipakai dalam }
$$

aplikasi E-commerce ini ialah consumer to consumer (C2C) yaitu aktifitas bisnis (penjualan) yang dilakukan oleh individu (konsumen) kepada individu (konsumen) lainnya dengan tujuan untuk melakukan proses transaksi jual beli. Consumer to Consumer (C2C) menjadi popular dibanyak kalangan karena terdapat komunitas besar dan berasal dari daerah yang sama. Sehingga dalam penelitian ini mencari alternatif untuk berjualan dan mencari media yang murah untuk menjual barang yaitu dengan menggunakan website pihak ketiga yaitu dengan dibuatnya sistem

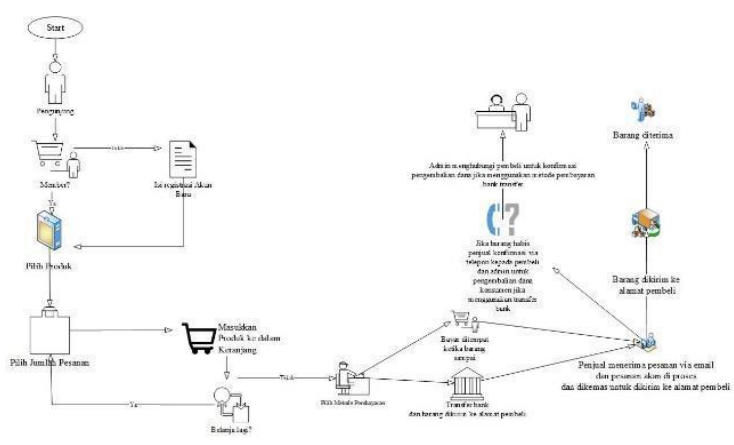

ini dan dapat dilihat alurnya pada Gambar sebagai berikut:

\section{Gambar 1. Alur Proses Bisnis}

\section{Analisis Sistem}

Tahap analisa kebutuhan sistem dilakukan analisa melalui wawancara dan pengumpulan data (kuisoner). Setelah melakukan sebuah analisa, untuk meningkatkan kualitas informasi yang dijadikan yaitu dibutuhkan suatu sistem informasi berbasis web yang memberikan layanan setiap waktu dalam media promosi yang bisa dinikmati setiap konsumen agar seluruh informasi mengenai barang apa saja yang tersedia mudah diakses.

\section{Analisis Perangkat}

a. Kebutuhan minimum hardware

Membangun aplikasi berbasis web tersebut perlu didukung oleh perangkat keras (hardware) yang memadai. Tabel 2.1, berikut ini merupakan spesifikasi minimum perangkat keras (hardware) untuk membangun sistem. 
Tabel 2.1 Kebutuhan Minimum Hardware

\begin{tabular}{|c|c|c|c|c|}
\hline No & $\begin{array}{c}\text { Nama } \\
\text { Hardware }\end{array}$ & Spesifikasi & Jumlah & Fungsi \\
\hline 1. & $\begin{array}{c}\text { PC (Personal } \\
\text { Computer) }\end{array}$ & $\begin{array}{l}\text { - Processor Intel(R) } \\
\text { Celeron(R) CPU } \\
847 @ 1.10 \mathrm{GHz} \\
\text { - } \text { Memori } 2,00 \mathrm{~GB} \\
\text { DDR3 } \\
\text { - Intel HD Graphics } \\
\text { - HDD } 320 \mathrm{~GB} \\
\text { - LCD } 14 \text { inches }\end{array}$ & $1 \mathrm{Set}$ & $\begin{array}{l}\text { Sebagai alat } \\
\text { antarmuka, } \\
\text { penampil dan } \\
\text { pengendali }\end{array}$ \\
\hline 2. & Printer & Canon IP 2770 & 1 Unit & $\begin{array}{c}\text { Alat untuk } \\
\text { mencetak } \\
\text { laporan }\end{array}$ \\
\hline 3. & Modem & ZTE-b1fbba & 1 unit & $\begin{array}{c}\text { Koneksi } \\
\text { internet }\end{array}$ \\
\hline
\end{tabular}

\begin{tabular}{|l|c|l|l|}
\hline No & Kebutuhan & \multicolumn{1}{|c|}{ Keterangan } & \multicolumn{1}{c|}{ Fungsi } \\
\hline 1. & Sistem Operasi & $\begin{array}{l}\text { Windows } 10 \\
\text { Enterprise }\end{array}$ & Sebagai OS utama \\
\hline 2. & Aplikasi Program & Notepad++ & Sebagai pengolah program \\
\hline 3. & Aplikasi Database & $\begin{array}{l}\text { XAMPP (Apache, } \\
\text { MySQL,PHP) }\end{array}$ & Sebagai pengolah database \\
\hline
\end{tabular}

\section{Perancangan Sistem}

\section{a. Use Case Diagram}

Model use case menjelaskan mengenai aktor-aktor yang terlibat dengan aplikasi sistem yang akan dibuat serta proses-proses yang ada didalamnya. Model use case dapat dilihat pada Gambar 3.1

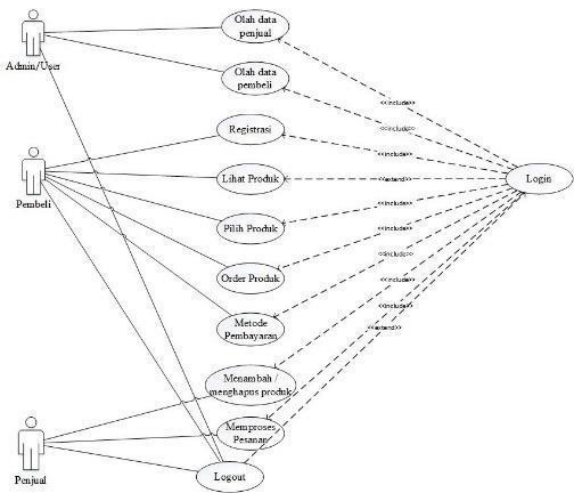

\section{b. Activity Diagram}

Activity diagram ialah salah satu cara untuk memodelkan event yang terjadi pada use case. activity diagram pada website toko oleh-oleh wisata Anyer

diantaranya Activity Diagram Registrasi, Activity Diagram Login, Activity Diagram Olah Data Penjual dan Pembeli, Activity Diagram Lihat Produk, Activity Diagram Pilih Produk, Activity Diagram Order Produk, Activity Diagram Metode

Pembayaran, Activity Diagram Menambah/Menghapus Produk, Activity Diagram Memproses Pesanan, dan Activity Diagram Logout.

Selain perangkat keras diperlukan juga perangkat lunak da c. Sequence Diagram

Sequence diagram merupakan diagram interaksi yang menampilkan

interaksi antara obyek untuk mengindikasikan sehingga terjadinya komunkasi. Berikut ini merupakan sequence diagram pada website tempat toko oleh-oleh wisata Anyer

1. Sequence Diagram Registrasi Akun Baru

Untuk sequence registrasi akun baru (Gambar 3.2) , dimana pembeli atau penjual baru agar daftar terlebih dahulu pada website toko oleholeh wisata Anyer sebelum memesan barang dan menjual produk

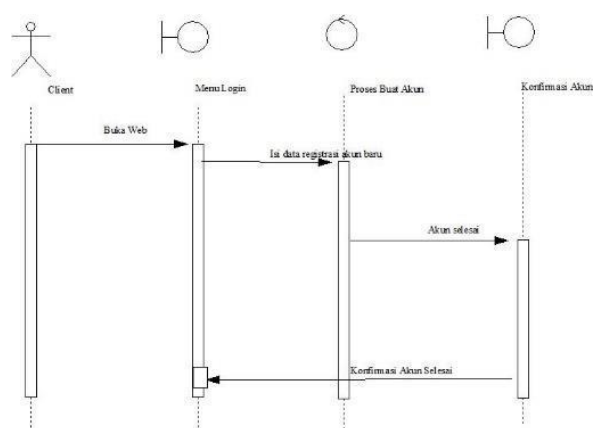

2. Sequence Diagram Login

Untuk Sequence Login (Gambar 3.3), actor yang berperan adalah penjual dan pembeli, dimana client masuk kedalam form login dan 
proses login yang kemudian akan diproses oleh server dan kemudian masuk ke halaman utama website, berikut diagramnya

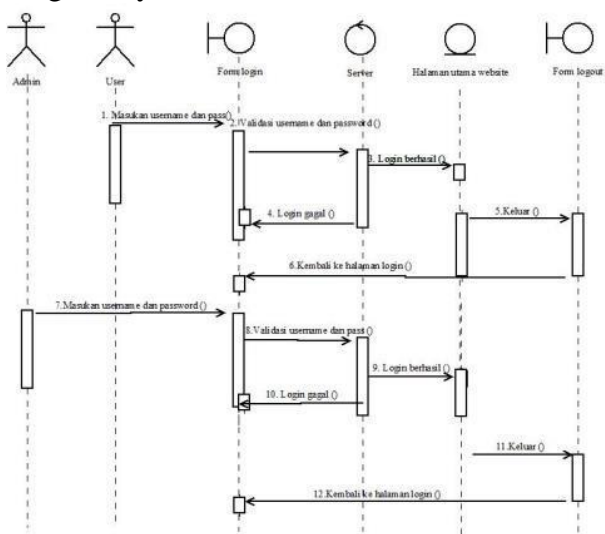

3. Sequence Diagram Lihat Produk Untuk Sequence lihat produk (Gambar 3.4), aktor yang berperan adalah pembeli, dimana pembeli masuk kedalam halaman utama website dan melihat produk dan kategori produk sebelum dipilih untuk dibeli, berikut diagramnya

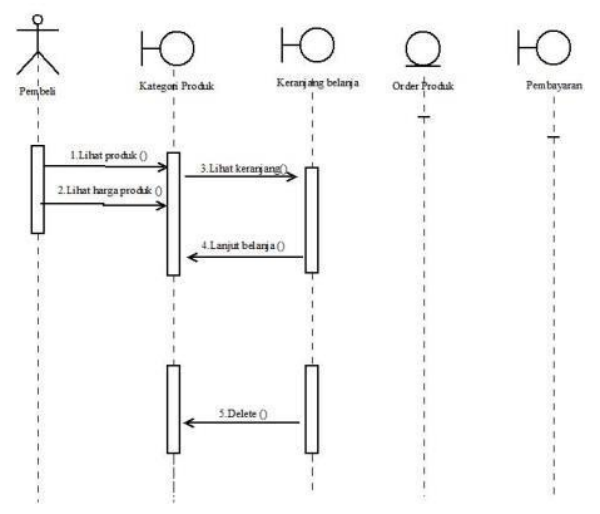

4. Sequence Diagram Pilih Produk

Untuk Sequence pilih produk (Gambar 3.5), aktor yang berperan adalah pembeli, dimana pembeli masuk kedalam halaman utama website dan melihat produk serta memilihnya dan memasukannya ke dalam keranjang pembelian

sebelum memasuki metode pembayaran, berikut diagramnya :

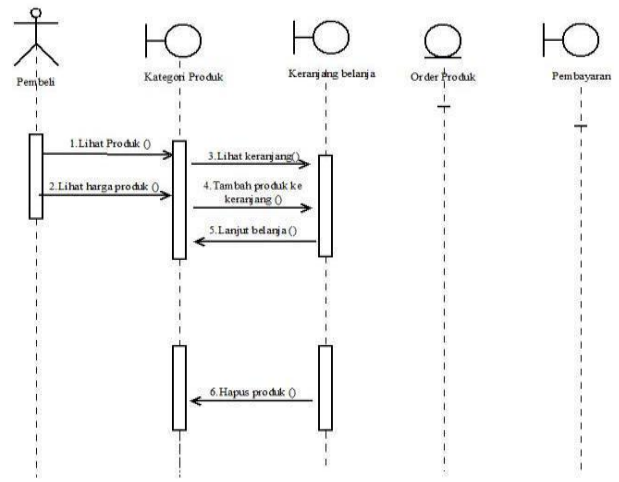

5. Sequence Diagram Order Produk Untuk Sequence order produk (Gambar 3.6), aktor yang berperan adalah pembeli, dimana pembeli sudah memilih produk yang akan

dibeli dan memasukannya kedalam keranjang pembelian lalu melakukan proses order produk dengan detail harga yang akan dibayar, berikut diagramnya :

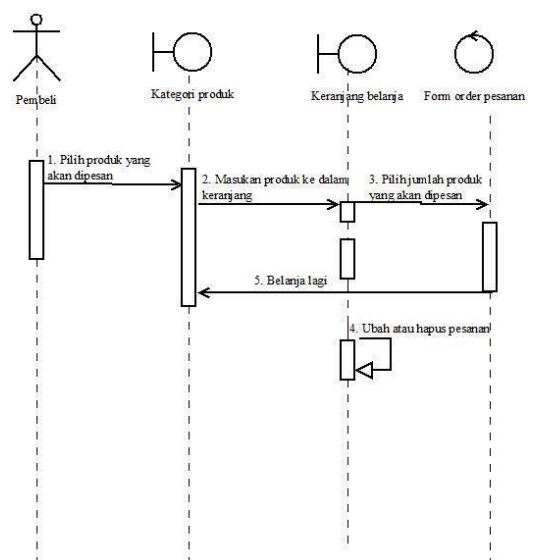

6. Sequence Diagram Metode Pembayaran

Untuk Sequence order produk ( Gambar 3.7), aktor yang berperan adalah pembeli, dimana pembeli sudah memasukan produk ke dalam keranjang dan akan memilih metode pembayaran yang akan dilakukan, berikut diagramnya : 


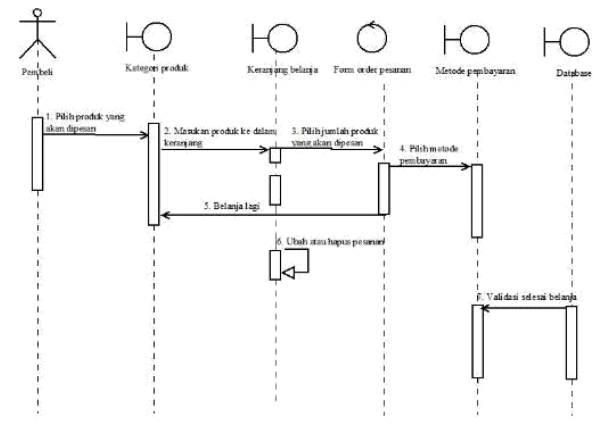

7. Sequence Diagram Menambah / Menghpus Produk

Untuk Sequence order produk (Gambar 3.8), aktor yang berperan adalah penjual, dimana penjual memasuki halaman utama website dan menambah produk serta menghapus produk yang sudah tidak tersedia, berikut diagramnya

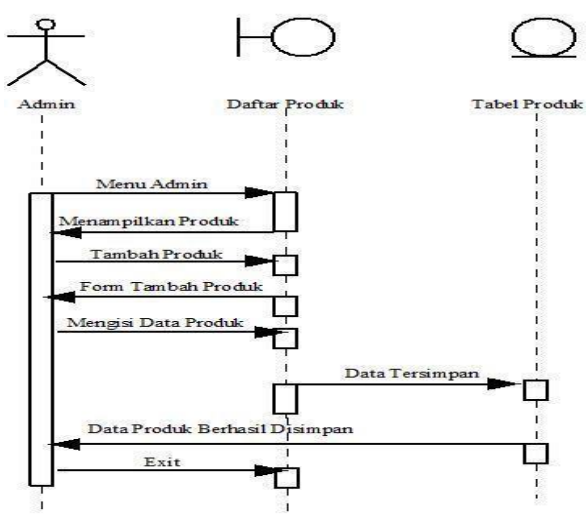

8. Sequence Diagram Proses Pesanan Untuk Sequence order produk (Gambar 3.9), aktor yang berperan adalah penjual, dimana penjual menerima pesanan dari pembeli lalu memprosesnya dan diakhiri dengan mengirim produk ke alamat pembeli, berikut diagramya :

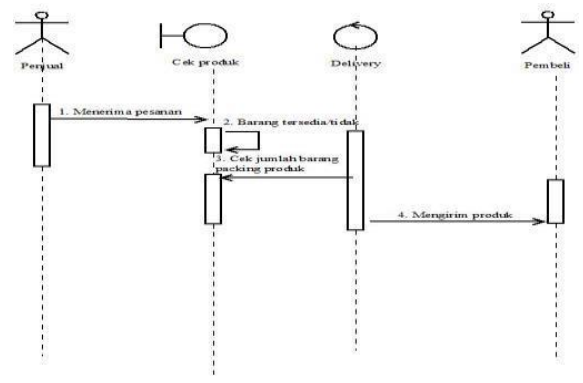

C. Class Diagram
Class diagram adalah diagram yang dipakai untuk menampilkan beberapa kelas yang ada pada sistem perangkat lunak yang akan siap

dikembangkan. Class diagram menunjukan beberapa hubungan antar class dalam proses pembangunan dan saling berkaitan untuk mencapai suatu tujuan. Berikut ini merupakan Gambar 3.10 class diagram untuk proses penerapan Implementasi website toko oleholeh Anyer

\section{d. Rancangan Basis Data}

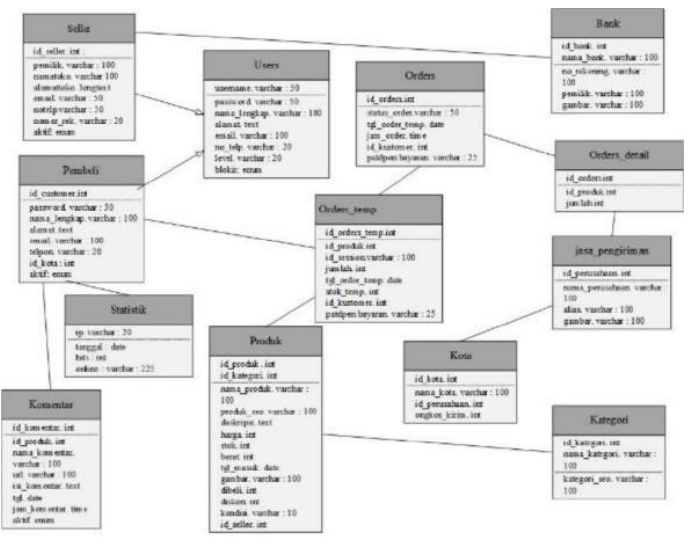

\begin{tabular}{l|l|l|l} 
No & \multicolumn{1}{|c|}{ Field } & Type & Size \\
\hline 1 & Username & varchar & 50 \\
\hline 2 & Password & varchar & 50 \\
\hline 3 & Nama_lengkap & varchar & 100 \\
\hline 4 & Email & varchar & 100 \\
\hline 5 & No_Telp & varchar & 20 \\
\hline 6 & Level & varchar & 20 \\
\hline 7 & Blokix & Enum &
\end{tabular}

\section{e. Perancangan}

Antarmuka

(Interface)

Berikut ini adalah tampilan antar muka dari website toko oleh-oleh wisata Anyer 1. Tampilan Buat Akun Baru Berikut ini adalah rancangan tampilan login pada website toko - oleh-oleh wisata Anyer yang dapat 
dilihat pada Gambar 3.11 sebagai berikut

2. Tampilan Halaman Menu

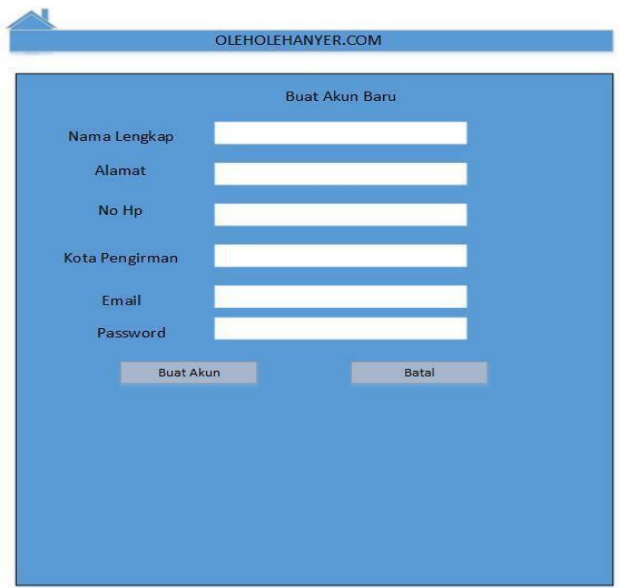

Utama

Berikut ini adalah rancangan tampilan halaman website menu utama pada toko oleh-oleh wisata Anyer yang dapat dilihat pada Gambar 3.12 sebagai berikut :

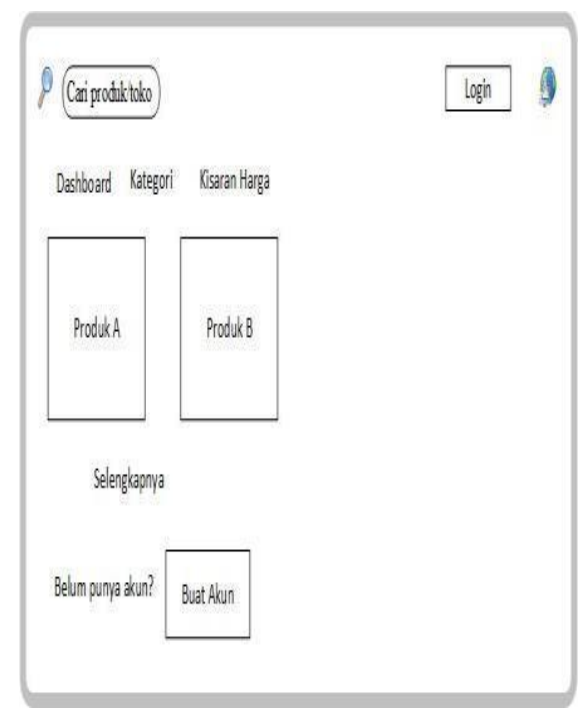

\section{HASIL DAN PEMBAHASAN}

\section{Deskripsi Sistem}

Deskripsi sistem website $E$ commerce toko oleh-oleh tempat wisata Anyer telah dirancang oleh peneliti dan diterapkan di toko-toko buah tangan khas daerah pariwisata Anyer. Berikut ini peneliti akan menampilkan halaman dengan memiliki fitur- fitur dan fungsinya masing-masing, yang antara lain sebagai berikut: a. Halaman Utama

Halaman utama merupakan tampilan awal sebagai informasi yang berkaitan dengan form-form yang dilakukan oleh user yaitu penjual dan pembeli. Aplikasi ini juga dapat digunakan oleh admin untuk melakukan penginputan data, mengolah database dan lain sebagainya. Berikut ini adalah Gambar 4.1 sebagai tampilan halaman utama website toko oleh-oleh tempat wisata Anyer.

b. Halaman Menu Admin

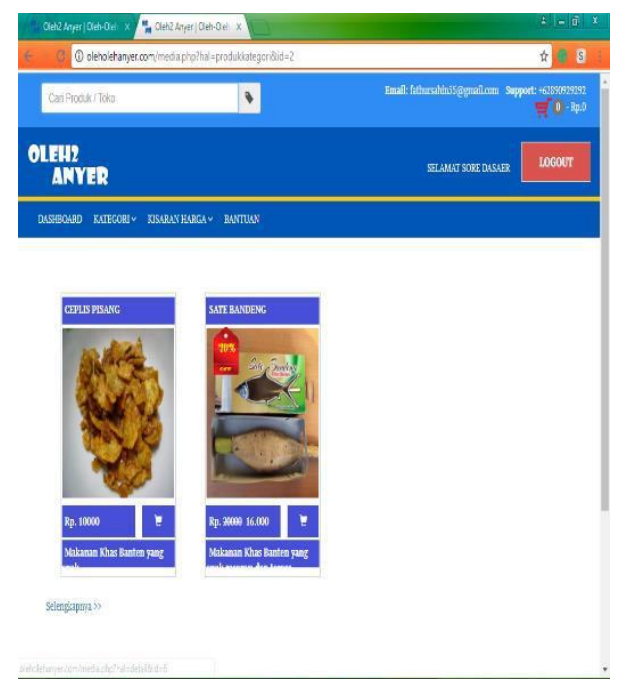

Jika proses login admin telah selesai maka sistem akan menampilkan halaman menu admin (Gambar 4.2) yaitu untuk mengolah data penjual dan pembeli juga dapat memblokir user yang tidak memenuhi syarat dan ketentuan 
Halaman utama admin, user mempunyai hak akses sebagai pengolah data penjual dan pembeli.

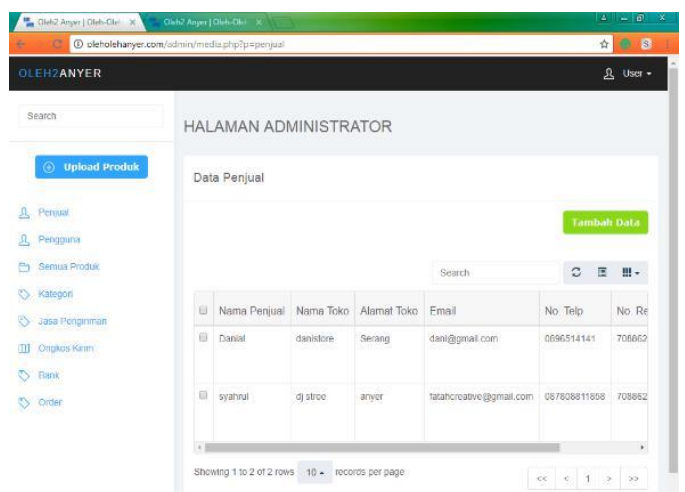

c. Halaman Menu Penjual

Apabila proses login telah selesai, sistem akan menampilkan menu penjual yang ada pada aplikasi (Gambar 4.3), dimana penjual bisa

memulai untuk mengupload produk, menghapus produk dan mengedit deskripsi produk.

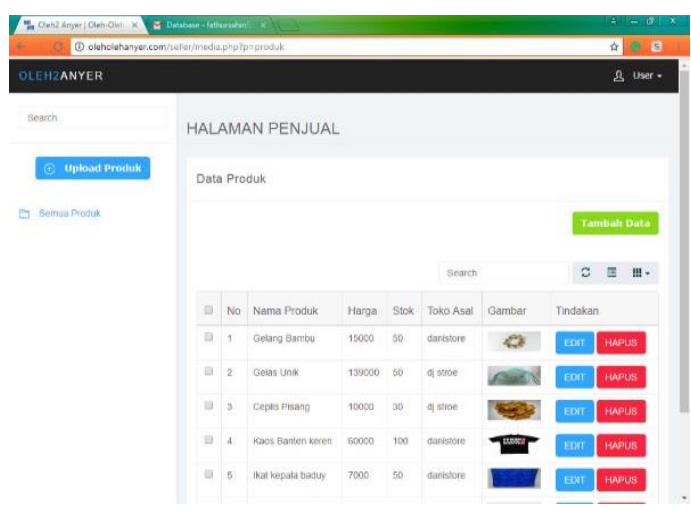

d. Tampilan Cara Order

Pada menu cara order (Gambar 4.11) yaitu pembeli telah selesai memilih produk dan memasukannya kedalam keranjang pembelian

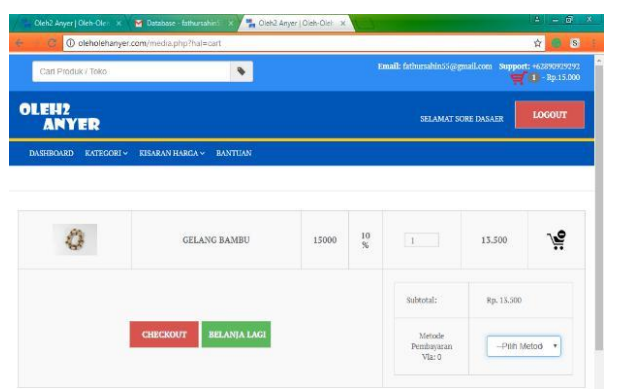

\section{Pengujian Sistem}

Tahap ini dilakukan pengujian sistem terhadap sistem yang telah dibuat dan dirancang dengan menggunakan metode pengujian black box testing sesuai dengan rancangan pengujian sistem website toko oleh-oleh tempat wisata Anyer. Berikut ini merupakan detail pengujian black box dapat dilihat Tabel 4.1 dibawah ini yaitu sebagai berikut:

\begin{tabular}{|c|c|c|c|}
\hline $\begin{array}{c}\text { Item } \\
\text { Pengujian }\end{array}$ & $\begin{array}{c}\text { Cara } \\
\text { Pengujian }\end{array}$ & $\begin{array}{c}\text { Hasil } \\
\text { Pengujian }\end{array}$ & Keterangan \\
\hline $\begin{array}{l}\text { Registrasi } \\
\text { Akun Baru }\end{array}$ & $\begin{array}{l}\text { Pada website toke } \\
\text { oleh-oleh tempat } \\
\text { wisata Anver }\end{array}$ & $\begin{array}{l}\text { Menampilkan form registrasi bagi } \\
\text { pembeli dan peniual guna } \\
\text { memiliki alun yang terdaftar. } \\
\text { dalam website }\end{array}$ & Selesai \\
\hline Login & $\begin{array}{c}\text { Rengisi username } \\
\text { dan password pada } \\
\text { halaman login }\end{array}$ & $\begin{array}{c}\text { Siatem menerima alsses login dan } \\
\text { mengarab ke balaman utama } \\
\text { masing-masing user }\end{array}$ & \\
\hline Input barang & Tambah Produk & $\begin{array}{l}\text { User penjual memilih form } \\
\text { tambah data, kemudian sistem } \\
\text { akan menampilkan form } \\
\text { penginputan data produk }\end{array}$ & Selesai \\
\hline & $\begin{array}{l}\text { Memulai Upload } \\
\text { Produk }\end{array}$ & $\begin{array}{l}\text { Uger Penjual setelah mengigi } \\
\text { seluruh data produk, user penjual } \\
\text { mengklik tombol simpan, yang } \\
\text { kemudian sistem akan langsung } \\
\text { mempublish pada website. }\end{array}$ & Selesai \\
\hline & Menghapus Produk & $\begin{array}{l}\text { User Penjual menglclik data } \\
\text { produlk kemudian memilith } \\
\text { mengharus procul maka produk } \\
\text { otomatis akun terhapus dari } \\
\text { sistem }\end{array}$ & Selesai \\
\hline Peasanan & Proses Resanan & $\begin{array}{c}\text { User Renjual mengetabui baboxa } \\
\text { ada pesanan yang masuk melalui } \\
\text { email, maka penjual segera } \\
\text { memprosea pesanan. }\end{array}$ & Selesai \\
\hline \multirow[t]{2}{*}{$\begin{array}{l}\text { Pembelian } \\
\text { Produk }\end{array}$} & Memilih Rroduk & $\begin{array}{l}\text { User pembeli memilih produk } \\
\text { pada kategori dan memasukannya } \\
\text { kedalam keranjang pembelian }\end{array}$ & Selesai \\
\hline & Konfirmasi Pesanan & $\begin{array}{c}\text { Jika user pembeli gudab } \\
\text { memasukan produk kedalam } \\
\text { keranjang pembelian, maka } \\
\text { dilaniutkan dengan mengklik } \\
\text { metode pembayaran yang tersedia } \\
\text { sehingga pesanan bisa segera } \\
\text { diproses }\end{array}$ & Selesai \\
\hline \multirow[t]{3}{*}{ Data Laporan } & Cetak Trangaksi & $\begin{array}{c}\text { Pada proses peaanan } \\
\text { user pembeli bisa mencetak data } \\
\text { trangaksi secara detail }\end{array}$ & Selesai \\
\hline & $\begin{array}{l}\text { Konfirmasi } \\
\text { Penerimaan }\end{array}$ & $\begin{array}{l}\text { User Rembeli mengklik tombel } \\
\text { terima barang anabila melabukan } \\
\text { pesanan via } \mathrm{COD} \text { (Cash On } \\
\text { Deliveny) sehingga bisa diketahui } \\
\text { bahwa order produk telah selesai }\end{array}$ & Selesai \\
\hline & Logout & $\begin{array}{l}\text { Pada menu ytama website } \\
\text { terdapat button logout yang } \\
\text { berfungsi apabila user ingin } \\
\text { keluar dari websize dan gistem } \\
\text { akan kembali kemenu halaman } \\
\text { utama. }\end{array}$ & Selesai \\
\hline
\end{tabular}




\section{SIMPULAN}

Berdasarkan penelitian yang telah peneliti lakukan maka dapat disimpulkan hasil penelitian yaitu sebagai berikut :

1. Setelah penelitian ini dilakukan, maka pemasaran produk dari penjual semakin

lebih mudah, serta memudahkan konsumen dalam melakukan pemesanan barang tanpa harus datang ke toko, yaitu dengan cara online melalui web site www.oleholehanyer.com.

2. Informasi produk-produk oleh-oleh yang ditampilkan yaitu dalam bentuk website sehingga konsumen dapat

membuka situs website untuk mendapatkan informasi produk dengan lengkap dan mudah.

3. Sistem penjualan dalam metode transaksi yang digunakan pada aplikasi E-Commerce ini menggunakan metode COD (Cash on delivery) atau bayar ditempat yang dikhususkan kepada wisatawan yang berada di Anyer dan metode transfer bank bagi pembeli yang berada diluar kota

\section{PUSTAKA}

Arip Ariyanto dan Tri Ariyanto. 2012. Pembangunan Sistem Penjualan Online Pada Toko Indah Jaya

Furniture. Jurnal Teknologi

$\begin{array}{lllll}\text { Informasi, } & \text { Vol. } & 04, & \text { No. } & 4 .\end{array}$

Universitas Surakarta.

David R. Kosiur. 1997. Understanding Electronic Commerce. United States : Washington, Microsoft Press

Dinar Sakti, Ridho. 2016. Perancangan Sistem Penjualan Berbasis Web

Pada Petshop Proplane

Universitas Muhammadiyah Ponorogo

Edi Winarno, dkk. 2011. Pemrograman Web Berbasis HTML 5, PHP, \& Javascript. Jakarta : Elex Media Komputindo
Fuady Munir. 2005. Pengantar Hukum Bisnis. Bandung : PT Citra Adi Bakti

Heni A Puspitosari . 2011. Pemrograman Web Database dengan PHP MySQL. Yogyakarta: Skripta Media Creative.

Ladjamudin, A. 2005. Analisis dan Desain Sistem Informasi. Yogyakarta: Graha Ilmu

Maryama Siti 2013. Penerapan ECommerce Dalam Meningkatkan Daya Saing Usaha. Vol. 2, No. 1. STIE Ahmad Dahlan. Jakarta.

Masrur Mukhamad. 2016. Pemrograman PHP dan MySQL Untuk Pemula. Yogyakarta: Andi, yogyakarta, madcoms.

McLeod, R. Dan Shell, G.P. 2004. Sitem Informasi Manajemen. Jakarta : Prenhallindo

Mugi Handayani SP dan Bambang Eka Purnama. 2014. Pembuatan Website E-Commerce Pada Distro Java Trend. Jurnal Teknologi Informasi, Vol. 02, No. 1. Universitas Surakarta.

Munawar Kholil .2008. E-Commerce. http://kholil.staff.uns.ac.id/files/2009 /03/ecommerce-k-051

Tanggal Akses : 14 Juni 2017

Nugroho Adi. 2008. E-commerce Memahami Perdagangan Modern di Dunia Maya. Bandung: Informatika

Rahardjo, Budi. 2005. Keamanan Sistem Informasi Berbasis Internet. Bandung : PT Insan Infonesia

Riyanto . 2011. Membuat Sendiri Aplikasi ECommerce dengan PHP \& MySQL Menggunakan Codelgniter \& JQuery. Yogyakarta: Andi, yogyakarta 
Sadeli Muhammad. 2014. Aplikasi Bisnis Maxikom. Dengan PHP MySQL. Palembang:

Saputra Agus, dkk. 2012. Membangun Aplikasi E-Library Untuk Panduan Skripsi. Jakarta : Elex Media Komputindo

Shim, J.K., Qureshi, A.A., Siegel, J.G., \& Siegel, R.M. 2000. The International HandBook Of Electronic Commerce, Chicago : Verlag

Sommerville, Ian. 2003. Software Engineering Rekayasa Perangkat Lunak. Jakarta : Erlannga

Suyanto, M 2003. E-Commerce Perusahaan Top Dunia. Yogyakarta : Andi, Yogyakarta

Turban, Efraim; David King; Lee Jae; Viehland, Dennis. 2004. Electronic Commerce : a Managerial Perspective 2004. (International Edition). Pearson Prentice Hall, New Jersey

Wilyani Fitri dkk. 2013. Peningkatan Daya Saing Bisnis Batik Kahuripan Melalui Sistem Penjualan Berbasis E-commerce.

Vol. 2, No. 1. Universitas Surakarta. 